\title{
温带荒漠区不同灌溉条件下的胡杨、俄罗斯杨水势变化 分析
}

\author{
付爱红，陈亚宁*，李卫红 \\ 中国科学院绿洲生态与荒漠环境重点实验室, 中国科学院新疆生态与地理研究所，乌鲁木齐 830011 \\ * 联系人, E-mail: chenyn@ms.xjb.ac.cn
}

2009-03-10 收稿, 2009-06-08 接受

国家自然科学基金(批准号: 40701052, 40871059)和中国科学院“西部之光”人才培养计划(编号: XBBS200804)资助项目

\begin{abstract}
摘要 测定植物水势被认为是现代灌水制度中确定何时灌水的直接途径. 以中亚准噶尔盆地 两种防护林物种——胡杨和俄罗斯杨为研究对象, 探讨不同灌溉条件下胡杨和俄罗斯杨的叶、 茎水势 $\left(\psi_{1}\right.$ 和 $\left.\psi_{\mathrm{s}}\right)$ 变化以及土壤水势 $\left(\psi_{\text {soil }}\right)$ 变化对胡杨和俄罗斯杨水势 $(\psi)$ 的影响. 研究结果表明: (1) 随着灌溉量的增加, 胡杨和俄罗斯杨受旱胁迫的强度逐渐减弱, 相同灌溉量下俄罗斯杨受 旱胁迫的强度比胡杨弱. (2) 环境越千旱, 俄罗斯杨对千旱反映的敏感程度越弱, 胡杨则越强, 反之亦然. (3) 胡杨群落地下 $60 \mathrm{~cm}$ 处土壤水势比地下 30 和 $90 \mathrm{~cm}$ 处土壤水势对灌溉量的变化 响应强烈, 俄罗斯杨群落较浅层土壤水势比较深层土壤水势对灌溉量的变化响应强烈. (4) 在 土壤水分较充足的情况下, 植物黎明前茎水势可作为反映土壤水势的合理指标. (5) 对胡杨和 俄罗斯杨防护林分别实施多量少灌和少灌多次的策略, 能满足胡杨和俄罗斯杨对水分的需求.
\end{abstract}

关键词 水势 $(\psi)$ 胡杨 俄罗斯杨 灌溉量 温带荒漠区
现代灌水制度中确定何时灌水有两种途径 ${ }^{[1]}$ : 一 种是直接测定土壤的水分含量或通过气象资料进行 土壤水分平衡计算来评估土壤水分的亏缺程度, 确 定是否需要灌水. 然而, 土壤水分亏缺程度并不能确 切的反映植物的水分亏缺状况, 植物的水分亏缺不 仅仅取决于土壤的水分状况, 它还与大气蒸发量的 变化、植物根系分布状况、植物体生长及生理活性、 水分输导能力、大气干湿度或饱和水蒸汽压等方面的 因素有关.土壤水分分布的不均匀性使通过测定土 壤水分状况确定灌水时间的方法更加困难. 另一种 是以植物为基础的测定, 如植物水势 $(\psi)$ 等. 植物 $\psi$ 的 测定是了解植物水分状况和确定灌水时间的最直接 方法, 这是因为植物 $\psi$ 反映土壤、植物和大气条件对 植物体内水分可利用性的综合影响. $\psi$ 是反映植物组织水分状况的一个重要生理指 标 ${ }^{[2]}$. 在干旱区, 水分是制约植物存活、生长繁殖和 分布的最主要因素. 灌溉后植物受早胁迫的强度明 显减轻, 植物 $\psi$ 明显增高. 植物 $\psi$ 能很好地反映灌溉 效应. 有关干旱胁迫下植物 $\psi$ 变化的研究, 主要是集 中研究对植物使用生长抑制剂、沙漠细菌和施肥等不 同处理后, 充足灌溉和干旱胁迫下植物 $\psi$ 的变化 ${ }^{[3 \sim 5]}$, 探讨植物不同生长期叶和茎水势 $\left(\psi_{1}\right.$ 和 $\left.\psi_{\mathrm{s}}\right)$ 对土壤水势 $\left(\psi_{\text {soil }}\right)$ 的响应. 对于植物 $\psi$ 能否有效反映土壤水分研 究方面, Donovan 等人 ${ }^{[6]}$ 研究得出当植物遭受严重的 干旱胁迫时，黎明前叶水势 $\left(\psi_{\mathrm{pd} 1}\right)$ 能有效反映当时的 土壤水分状况, 当植物未遭受干旱胁迫时, $\psi_{\mathrm{pdl}}$ 不能 很好地反映当时的土壤水分状况; Cutchan 等人 ${ }^{[7]}$ 研 究发现午间叶水势 $\left(\psi_{\mathrm{ml}}\right)$ 比午间茎水势 $\left(\psi_{\mathrm{ms}}\right)$ 能更好地 
反映当时的土壤水分状况; 但是, Atklnson 等人 ${ }^{[8]}$ 却 研究发现 $\psi_{1}$ 与土壤水分之间存在紧密的联系. 对于 植物 $\psi_{1}$ 和 $\psi_{\mathrm{s}}$ 日变化特征的研究, 白瑞琴等人 ${ }^{[9]}$ 研究发 现在土壤水分相对充足的情况下，植物 $\psi_{1}$ 和 $\psi_{\mathrm{s}}$ 日变 化呈明显的“V”型单峰曲线; 曾凡江等人 ${ }^{[10]}$ 研究发现 在土壤水分相对不足的情况下，植物 $\psi_{1}$ 和 $\psi_{\mathrm{s}}$ 日变化 呈不明显的“V”型单峰曲线. 由此可知, $\psi$ 日变化能否 呈现“V”型趋势与土壤水分的亏缺程度或植物遭受水 分胁迫的程度有关. 土壤水分越充足, 植物受早胁迫 的强度越弱， $\psi$ 日变化呈现的“V”型趋势越明显，反之， $\psi$ 日变化呈现的“V”型趋势不明显或不呈现“V”型趋 势. $\psi$ 最高值出现的时间反映植物 $\psi$ 与 $\psi_{\text {soil }}$ 达到平衡的 时间，而 $\psi$ 最低值出现时间的早晚反映植物对水分胁 迫敏感程度的强弱，在相同的水分胁迫状况下， $\psi$ 最 低值出现的时间越早, 表明植物对水分胁迫的敏感 程度越强, 反之亦然. 研究植物 $\psi$ 的日变化特征可反 映植物的受旱和抗旱特性，对确定合理地灌溉时间、 灌 溉量, 提高灌溉效率具有重要的实际 意义.

胡杨具有耐旱、抗寒、耐沙埋、耐盐碱、寿命长、 病虫害少、适应性广、萌摹力强等特点, 是干旱沙漠 里天然生长的唯一乔木树种, 是荒漠地区和盐碱地 造林的先锋树种 ${ }^{[11]}$. 俄罗斯杨具有成活率高、生长速 度快、生长量大、耐旱、耐寒、抗逆性强的特点, 常 作为农田防护林造林树种或绿化树种 ${ }^{[12]}$. 目前, 关 于胡杨的研究主要是分析中国新疆塔里木河下游生 态输水对胡杨生理生态的影响 ${ }^{[13]}$, 运用 DNA 方法分 析中国西北胡杨群落的遗传多样性 ${ }^{[14]}$, 研究盐分和 渗透胁迫对胡杨脯氨酸和糖分积累的影响 ${ }^{[15]}$ 以及胡 杨的抗盐性 ${ }^{[16]}$. 关于胡杨 $\psi$ 的研究多集中于胡杨 $\psi$ 的 日、月变化特征及其与环境因子的关系 ${ }^{[1,17,18]}$, 对不 同灌溉量下胡杨 $\psi$ 的变化研究较少; 关于俄罗斯杨的 研究主要是注重其栽培模式和造林技术的研究 ${ }^{[19]}$, 缺乏对俄罗斯杨 $\psi$ 变化特征及其对不同灌溉量的响 应研究. 探讨胡杨和俄罗斯杨 $\psi$ 对不同灌溉量的响应, 可为提高灌溉效率、提出有效的节水灌溉造林策略提 供本底资料。

本文通过对新疆北部准噶尔盆地不同灌溉量下 胡杨和俄罗斯杨的 $\psi_{1}$ 和 $\psi_{\mathrm{s}}$ 及其 $\psi_{\mathrm{soil}}$ 变化的监测研究, 分析了胡杨和俄罗斯杨 $\psi_{1}$ 和 $\psi_{\mathrm{s}}$ 及其 $\psi_{\text {soil }}$ 日变化对不 同灌溉量的响应特征，探讨了 $\psi_{\text {soil }}$ 变化对胡杨和俄罗 斯杨 $\psi$ 的影响，并提出了节水灌溉造林策略.

\section{1 材料与方法}

\section{1 研究区概况}

研究区位于新疆准噶尔盆地克拉玛依的新旺农 业开发区, 该区以湖相沉积为主，属于古玛纳斯湖 的湖盆. 土壤质地黏重致密、板结，盐渍化问题严重. 该区属典型的温带荒漠区，大陆性气候特征显著， 夏季干热, 冬季严寒, 年均气温可达 $8^{\circ} \mathrm{C}$; 年降水量 多年平均为 $105.3 \mathrm{~mm}$, 全年潜在蒸发量达 $3545 \mathrm{~mm}$. 春季多风, 全年 $>5$ 级风的日数为 $119.7 \mathrm{~d}, \geqslant 8$ 级风 的日数为 $45.6 \mathrm{~d}$, 最大风速可达 $25.1 \mathrm{~m} / \mathrm{s}$, 主风向西 北 $^{[15]}$.

\section{2 实验设计}

本项试验研究在克拉玛依农业开发区的骨干防 护林带开展(图 1), 主要选取防护林中的胡杨和俄罗 斯杨为研究对象. 首先, 将该区平均分成 $\mathrm{A}, \mathrm{B}$ 和 $\mathrm{C} 3$ 块试验地, 每块试验地面积分别约为 $0.33 \mathrm{hm}^{2}$, 每块 试验地均由 20 排胡杨和 20 排俄罗斯杨构成. 于 2008 年 5 月份和 6 月份对试验地 A, B 和 C 分别累积 实施了 0,80 和 $200 \mathrm{~m}^{3}$ 的灌溉量. 5 月 10 日、 5 月 20 日、6月 10 日和 6 月 20 日 4 次对试验地 $\mathrm{B}$ 和 C 实施 灌溉, B 和 $\mathrm{C}$ 试验地的灌溉定额分别为 60 和 $150 \mathrm{~m}^{3} /$ (次 $\cdot \mathrm{hm}^{2}$ ), 因每块试验地面积均约为 $0.33 \mathrm{hm}^{2}$, 第一 次灌溉后, 对 $\mathrm{B}$ 和 $\mathrm{C}$ 试验地实施的灌溉量分别达到约 20 和 $50 \mathrm{~m}^{3}, 4$ 次灌溉后, 灌溉量分别累积达到 80 和 $200 \mathrm{~m}^{3}$, 灌溉频率保持一致. 在 3 块试验地的胡杨和 俄罗斯杨群落里, 分别选 1 个 $25 \mathrm{~m} \times 25 \mathrm{~m}$ 的正方形小 样方, 在每个样方内各选取 3 棵生长状况良好的胡 杨或俄罗斯杨植株为研究对象, 胡杨年龄平均为 10 年, 树高 12 15 m, 胸径 25 30 cm; 俄罗斯杨年龄平 均为 10 年, 树高 $20 \sim 25 \mathrm{~m}$, 胸径 $15 \sim 20 \mathrm{~cm}$.

\section{3 植物水势的测定}

胡杨和俄罗斯杨的 $\psi_{1}$ 和 $\psi_{\mathrm{s}}$ 采用美国 WESCOR 公 司生产 HR-33T 露点水势仪(Dew Point Microvolt-meter) 实地测定得到. 在试验地 $\mathrm{A}, \mathrm{B}$ 和 $\mathrm{C}$ 分别选 择生长状况良好的胡杨和俄罗斯杨各 3 棵, 在所选 样株的向阳面选择树冠中上部发育正常的叶片各 3 片，立即装入密封聚乙烯塑料袋中，随后，在生长状 况良好的叶片上, 避开叶脉剪接直径 $5 \mathrm{~mm}$ 小叶片 3 片，分别置于露点水势仪的 3 个 C-52 样品室内, 将 


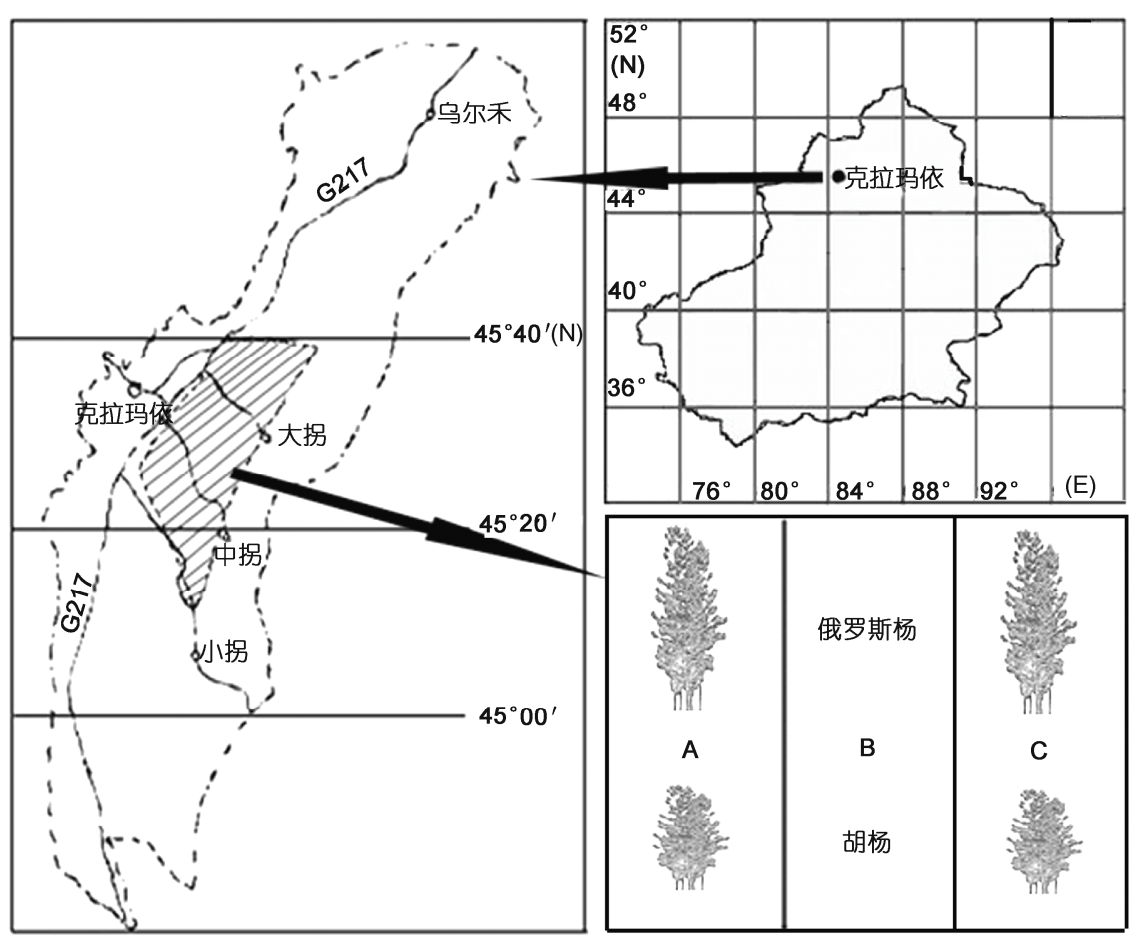

图 1 新疆克拉玛依农业开发区研究区示意图

$\mathrm{V}$ 是新疆克拉玛依农业开发区; $\mathrm{A}, \mathrm{B}$ 和 C 是研究区样地

这 3 个样品室与水势仪连接进行水热平衡. 由于植 物样品带有表皮, 故需对植物样品和样品室空气平 衡 $4 \mathrm{~h}$ 后才能进行水势的测定. 平衡完成后, 根据样 品室温度和传感器型号设置适宜的 $\Pi \mathrm{v}$ 值(称致冷系 数), 读取 $\mu_{\mathrm{v}}$ 值(称露点读数), 按照 $\mu_{\mathrm{v}} / 7.5$ 计算被测 叶水势值 $(\mathrm{MPa})$. 植物茎水势的测量过程与叶水势的 测量过程基本相同, 只是所选长约 $3 \mathrm{~mm}$ 、直径约 1.5 2.0 $\mathrm{mm}$ 的小枝位于连接所选叶片的下端茎干处. 本实验拥有 6 个 C-52 样品室, 每天只对一种植物的 叶或茎的水势进行日变化测定. 测量过程中 6 个样 品室轮流使用, 具体来看, 黎明前(约 6:00 左右)使用 3 个样品室进行样品与样品室的水热平衡, 10:00 时 刻测定 $\psi_{\mathrm{pd}}$ 数据, 同时采集 10:00 时刻植物样品, 使 用另外 3 个样品室进行该样品与样品室空气的水热 平衡, 依次进行各测量时间点的平衡和测定. 将以日 出前 $20 \mathrm{~min}$ 的水势测定值作为植物 $\psi_{\mathrm{pd}}$, 野外测定均 选择在晴朗无云的天气进行. 于 4 次灌水后 $30 \mathrm{~d}$, 即 从 2008 年 7 月 20 日开始对胡杨和俄罗斯杨 $\psi_{1}$ 和 $\psi_{\mathrm{s}}$ 的日变化进行测定, $\psi_{\mathrm{pd}}$ 测完后, 从 10:00 20:00每隔 $2 \mathrm{~h}$ 取样 1 次, 对每个试验地胡杨和俄罗斯杨 $\psi_{1}$ 和 $\psi_{\mathrm{s}}$ 均进行 9 个重复, 求平均值. 测定共需 $18 \mathrm{~d}$.

\section{4 土壤水势的测定}

$\Psi_{\text {soil }}$ 同样采用美国 WESCOR 公司生产 HR-33T 露点水势仪测定得到, 测量前使用本仪器所配备的 型号为 PSF-55-15-SF 和 PSF-55-30-SF 土壤探头共 18 个. 在试验地 $\mathrm{A}, \mathrm{B}$ 和 $\mathrm{C}$ 内, 以被测胡杨和俄罗斯杨 群落的土壤为研究对象, 在 3 块试验地的胡杨和俄罗 斯杨群落内任意各挖深约 $1 \mathrm{~m}$ 的土坑 3 个, 共挖 18 个坑, 在每个坑的地下 30,60 和 $90 \mathrm{~cm}$ 处各插人土壤 探头 1 个, 然后, 将土坑填埋, 探头的测量插口露在 地表, 为能清晰辨认这些插口分别代表哪个深度处 的探头, 将这些插口分别放人标有不同深度的自封 带中. 埋在坑里的探头平衡 $24 \mathrm{~h}$ 后, 同样, 采用 HR-33T 露点水势仪对地下不同深度处 $\psi_{\text {soil }}$ 的日变化 进行测定, 从黎明前 20:00 每隔 $2 \mathrm{~h}$ 测定 1 次, 重复 3 次测量, 求平均值.

\section{5 数据分析}

利用 Excel 软件进行数据分析与作图. 描述性统 计用于计算重复的平均值和标准方差, 平均值的标 准方差用误差线表示. 使用 ANOVA 方差分析比较每 种灌溉条件下植物 $\psi_{1}$ 和 $\psi_{\mathrm{s}}$ 日变化 9 个重复测量之间 
差异的显著性.

\section{2 结果与分析}

\section{1 不同灌溉量对植物水势日变化的影响}

图 2 表明不同灌溉量下胡杨和俄罗斯杨 $\psi_{1}$ 和 $\psi_{\mathrm{s}}$ 的日变化. 由图 2 可知, 胡杨和俄罗斯杨 $\psi_{1}$ 日变化对 不同灌溉量的响应各不相同. 当不实施灌溉时, 胡杨 和俄罗斯杨 $\psi_{1}$ 日变化均呈不明显的“V”型单峰趋势, $\psi_{\mathrm{pd}}$ 最高, 分别达-2.65 和-3.00 MPa, 午后 18:00 $\psi$ 最 低, 达-5.08 和-6.80 MPa, 在 20:00 时刻出现些许升 高迹象, 说明胡杨和俄罗斯杨均已遭受严重的干旱 胁迫. 在实施 $80 \mathrm{~m}^{3}$ 灌溉量后, 胡杨和俄罗斯杨 $\psi_{1}$ 的 日变化均呈明显的“V”型单峰趋势, $\psi_{\mathrm{pd}}$ 最高, 分别达 -2.30 和-2.00 MPa, 而后, 随着气温的升高 $\psi$ 逐渐降 低, 胡杨 $\psi_{1}$ 最低值出现在正午 14:00 时刻, 达-4.60 $\mathrm{MPa}$, 俄罗斯杨 $\psi_{1}$ 最低值出现在午后 16:00 时刻, 达 -6.24 MPa, 之后 $\psi$ 开始回升. 胡杨和俄罗斯杨 $\psi_{1}$ 均 于黎明前达最高, 说明它们均在这时与 $\psi_{\text {soil }}$ 达到平衡 状态. 胡杨 $\psi_{1}$ 最低值出现的时间与俄罗斯杨相比有 所提前, 说明实施 $80 \mathrm{~m}^{3}$ 灌溉量后胡杨对水分胁迫的 敏感程度比俄罗斯杨强烈. 在 $200 \mathrm{~m}^{3}$ 灌溉量下, 胡
杨 $\psi_{1}$ 日变化基本表现出“先升高-后降低-再升高”的变 化趋势, 胡杨 $\psi_{1}$ 日变化 9 个重复测量值之间的差异 不显著 $(\operatorname{Sig} .=0.326)$; 而俄罗斯杨 $\psi_{1}$ 日变化表现出“先 升高-后降低-再升高-再降低”的变化趋势, 俄罗斯杨 $\psi_{1}$ 日变化 9 个重复测量值之间的差异也不显著 $(\mathrm{Sig} .=0.455)$. 两种植物 $\psi_{1}$ 均于上午 10:00 时刻达最高, 分别为 -1.89 和-2.69 $\mathrm{MPa}$, 与实施 $80 \mathrm{~m}^{3}$ 灌溉量后 $\psi_{1}$ 最高值出现的时间相比有所推迟, 这可能是因为实 施 $200 \mathrm{~m}^{3}$ 灌溉量后 $\psi_{\text {soil }}$ 高于 $80 \mathrm{~m}^{3}$ 灌溉量后 $\psi_{\text {soil }}$, 植 物恢复到与 $\psi_{\text {soil }}$ 相平衡时所需时间较长; 胡杨 $\psi_{1}$ 最低 值出现在午后 16:00 时刻, 达-3.44 MPa, 俄罗斯杨 $\psi_{1}$ 最低值出现在正午 14:00 时刻, 达-5.93 $\mathrm{MPa}$, 这 与实施 $80 \mathrm{~m}^{3}$ 灌溉量后胡杨和俄罗斯杨 $\psi_{1}$ 最低值出现 的时间正好相反, 说明实施 $200 \mathrm{~m}^{3}$ 灌溉量后俄罗斯 杨对水分变化的敏感程度比胡杨强烈.

由图 2 还可看出, 胡杨和俄罗斯杨 $\psi_{\mathrm{s}}$ 日变化对不 同灌溉量的响应也各不相同. 当不实施灌溉时, 胡杨 和俄罗斯杨 $\psi_{\mathrm{s}}$ 日变化均表现出逐渐降低的变化趋势, $\psi_{\mathrm{pd}}$ 最高, 分别达-4.20 和-3.20 MPa, 20:00 时刻最低, 达-8.20 和-6.20 MPa, 未出现升高迹象, 说明胡杨和 俄罗斯杨均遭受严重的干旱胁迫. 当灌溉量达 $80 \mathrm{~m}^{3}$
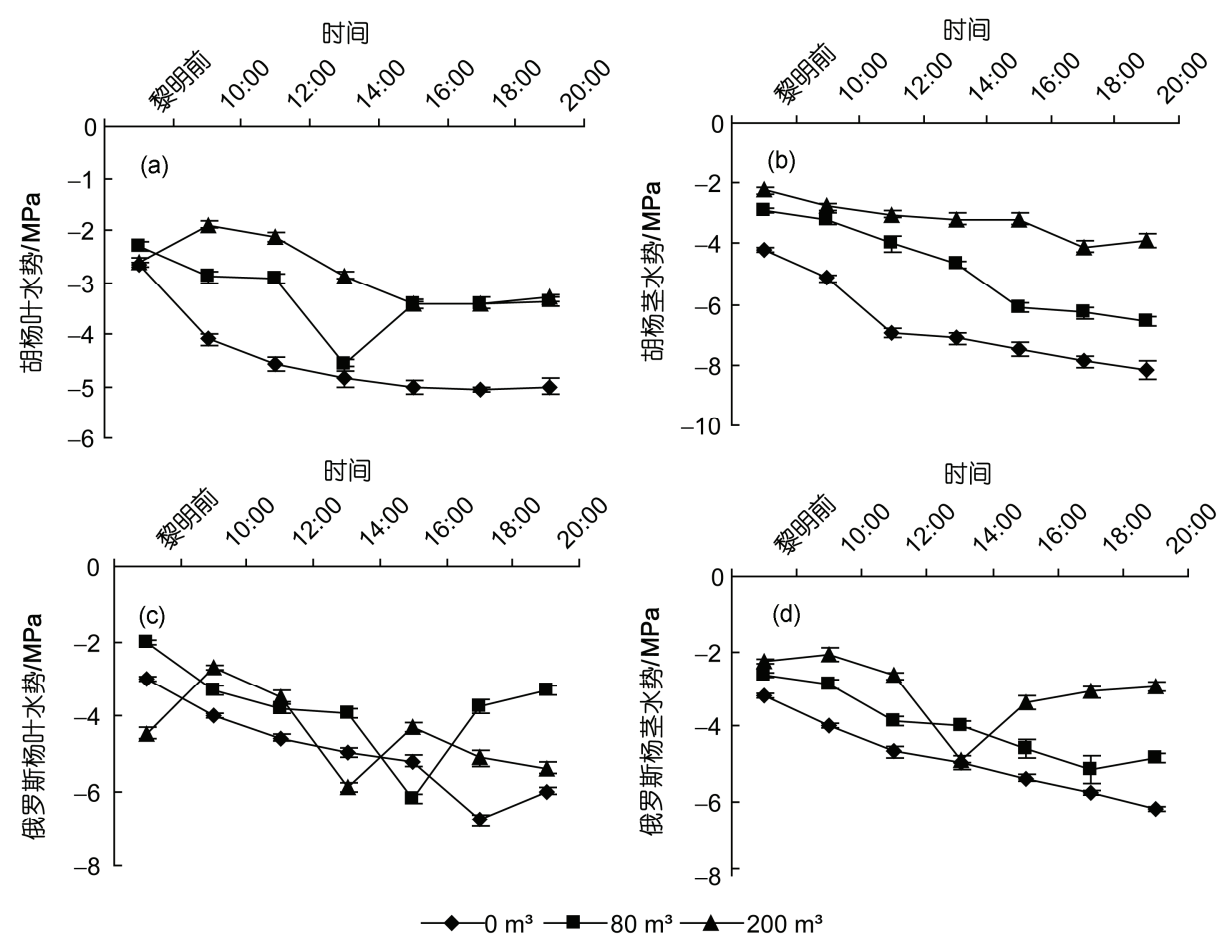

图 2 不同灌溉量下胡杨 $((\mathbf{a}),(\mathbf{b}))$ 和俄罗斯杨 $((\mathbf{c}),(\mathbf{d}))$ 叶和茎水势的日变化 
时, 胡杨和俄罗斯杨 $\psi_{\mathrm{s}}$ 日变化均表现出 $\psi_{\mathrm{pd}}$ 最高, 分 别达-2.91 和-2.64 MPa, 随后逐渐降低, 下午 20:00 时刻, 俄罗斯杨 $\psi_{\mathrm{s}}$ 出现些许升高迹象, 显著性水平 Sig. 达 0.287 , 但胡杨 $\psi_{\mathrm{s}}$ 未出现明显恢复过程. 这说明 实施 $80 \mathrm{~m}^{3}$ 灌溉量后胡杨所遭受的水分亏缺程度比俄 罗斯杨强烈. 当灌溉量达 $200 \mathrm{~m}^{3}$ 时, 胡杨 $\psi_{\mathrm{s}}$ 日变化 呈不显著地“V”型单峰趋势, 最高值出现在黎明前, 达-2.25 MPa, 而后, 随着气温的升高 $\psi_{\mathrm{s}}$ 逐渐下降, 最低值出现在午后 18:00 时刻, 为 $-4.10 \mathrm{MPa}$, 之后 $\psi$ 开始回升. 俄罗斯杨 $\psi_{\mathrm{s}}$ 日变化呈明显地“V”型单峰趋 势, 10:00 时刻 $\psi_{\mathrm{s}}$ 最高, 达-2.07 MPa, 14:00 时刻 $\psi_{\mathrm{s}}$ 最 低, 达-4.91 MPa，随后 $\psi$ 开始回升.

从胡杨 $\psi$ 日变化特征来看, 不论是实施 0,80 还 是 $200 \mathrm{~m}^{3}$ 灌溉量, 午后胡杨 $\psi_{1}$ 均先于 $\psi_{s}$ 回升. 具体来 看, 当不实施灌溉时, 胡杨 $\psi_{1}$ 于下午 20:00 出现些许 升高迹象, 但 $\psi_{\mathrm{s}}$ 却未明显回升; 实施 $80 \mathrm{~m}^{3}$ 灌溉量后, 胡杨 $\psi_{1}$ 于午间 14:00 以后开始回升, 而胡杨 $\psi_{\mathrm{s}}$ 却直到 下午 20:00 时刻都未显示明显回升迹象; 实施 $200 \mathrm{~m}^{3}$ 灌溉量后, 胡杨 $\psi_{1}$ 于午后 16:00 开始回升, 而胡杨 $\psi_{\mathrm{s}}$ 却于午后 18:00 才开始回升. 这可能是因为在水分亏 缺条件下气孔关闭降低叶片蒸腾, 蒸腾拉力的减小阻 止叶水势进一步降低, 同时, 土壤无法及时将水分输 送到茎干, 导致茎干水势一直无法回升, 当气温下降、 关闭后的气孔重新打开、蒸腾拉力增大时, $\psi_{\mathrm{s}}$ 才开始 回升. 对于俄罗斯杨而言, 当不实施灌溉时, 俄罗斯 杨 $\psi_{1}$ 于下午 20:00 开始回升, 但 $\psi_{\mathrm{s}}$ 并未回升; 实施 80 $\mathrm{m}^{3}$ 灌溉量后, 午后 $\psi_{1}$ 先于 $\psi_{\mathrm{s}}$ 回升; 实施 $200 \mathrm{~m}^{3}$ 灌溉量 后, $\psi_{1}$ 和 $\psi_{\mathrm{s}}$ 均于午间 14:00 以后开始回升, 说明对俄 罗斯杨实施 $200 \mathrm{~m}^{3}$ 灌溉量后, 俄罗斯杨已不遭受水 分胁迫, 可以正常生长发育.

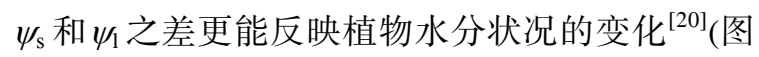
3). $\psi_{\mathrm{s}}$ 和 $\psi_{1}$ 之差越大, 表明土壤水分供应越充足, 植 物水分状况越好; 其差值越小, 表明土壤水分供应越 不足, 植物水分状况越差 ${ }^{[20]}$. 通过分析 0,80 和 200 $\mathrm{m}^{3}$ 灌溉量下胡杨和俄罗斯杨 $\psi_{\mathrm{s}}$ 和 $\psi_{1}$ 之差(图 3), 发现 在 0 和 $80 \mathrm{~m}^{3}$ 灌溉量下, 胡杨 $\psi_{\mathrm{s}}$ 和 $\psi_{1}$ 之间的差值很小, 且均为负值, 说明胡杨水分状况较差, 受旱胁迫程度 较强; 俄罗斯杨 $\psi_{\mathrm{s}}$ 和 $\psi_{1}$ 之间的差值较小, 说明俄罗斯 杨受旱胁迫程度较弱. 在对胡杨和俄罗斯杨实施 200 $\mathrm{m}^{3}$ 灌溉量时, 胡杨 $\psi_{\mathrm{s}}$ 和 $\psi_{1}$ 之差较小, 而俄罗斯杨 $\psi_{\mathrm{s}}$ 和 $\psi_{1}$ 之差很大, 且均为正值, 说明在 $200 \mathrm{~m}^{3}$ 灌溉量 下, 俄罗斯杨水分状况良好, 而胡杨水分状况较差.
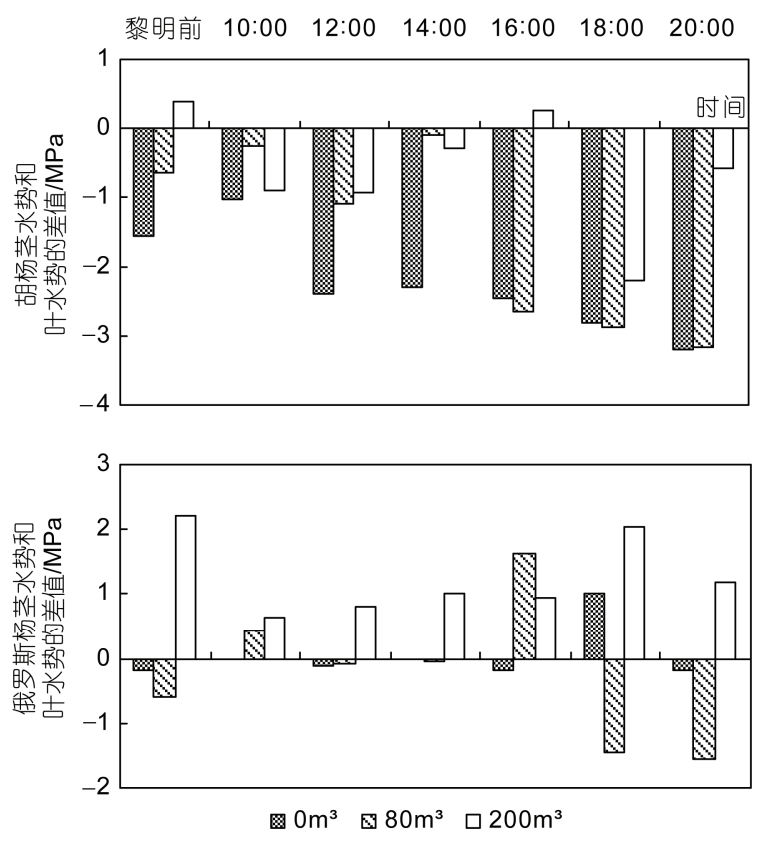

图 3 胡杨和俄罗斯杨茎、叶水势差值的日变化

由此可知, $200 \mathrm{~m}^{3}$ 灌溉量可以满足俄罗斯杨正常生 长所需, 但不能满足胡杨正常生长. 在相同灌溉量 下, 俄罗斯杨受旱胁迫强度比胡杨弱, 这可能与俄 罗斯杨主要依靠浅根系吸水而胡杨主要靠深根系吸 水有关.

\section{2 不同灌溉量对土壤水势日变化的影响}

通过对胡杨和俄罗斯杨实施 0,80 和 $200 \mathrm{~m}^{3}$ 灌溉 量后地下 30,60 和 $90 \mathrm{~cm}$ 处 $\psi_{\text {soil }}$ 日变化的分析可以看 出(图 4), 不论是地下 30,60 , 还是 $90 \mathrm{~cm}$, 实施 $80 \mathrm{~m}^{3}$ 灌溉量后 $\psi_{\text {soil }}$ 高于 $0 \mathrm{~m}^{3}$ 灌溉量后 $\psi_{\text {soil }}, 200 \mathrm{~m}^{3}$ 灌溉量 后 $\psi_{\text {soil }}$ 高于 $80 \mathrm{~m}^{3}$ 灌溉量后 $\psi_{\text {soil }}$, 说明灌溉对地下 90 $\mathrm{cm}$ 内 $\psi_{\text {soil }}$ 影响强烈. 当灌溉量由 $0 \mathrm{~m}^{3}$ 达到 $200 \mathrm{~m}^{3}$ 时, 胡杨群落地下 $60 \mathrm{~cm}$ 处 $\psi_{\text {soil }}$ 增幅大于地下 30 和 $90 \mathrm{~cm}$ 处 $\psi_{\text {soil }}$ 增幅, 表明胡杨群落地下 $60 \mathrm{~cm}$ 处 $\psi_{\text {soil }}$ 对灌溉量 的变化响应强烈; 俄罗斯杨群落地下 30,60 和 $90 \mathrm{~cm}$ 处 $\psi_{\text {soil }}$ 的增幅依次减小, 说明俄罗斯杨群落较浅层 $\psi_{\text {soil }}$ 比较深层 $\psi_{\text {soil }}$ 对灌溉量变化响应强烈.

\section{3 不同土壤水势下植物水势变化}

图 5 为不同 $\psi_{\text {soil }}$ 状况下胡杨和俄罗斯杨 $\psi_{\mathrm{pd}}$ 和 $\psi_{\mathrm{m}}$ 的变化. 由图 5 可知, 随着 $\psi_{\mathrm{soil}}$ 的升高, $\psi_{\mathrm{pds}}, \psi_{\mathrm{ml}}$ 和 $\psi_{\mathrm{ms}}$ 均升高, 但 $\psi_{\mathrm{pdl}}$ 则降低. 具体来看, 当 $\psi_{\mathrm{soi}}$ 由 -0.25 $\mathrm{MPa}$ 降低到- $0.58 \mathrm{MPa}$ 时, 俄罗斯杨 $\psi_{\mathrm{pdl}}$ 由 $-4.50 \mathrm{MPa}$ 
升高到-2.00 MPa, 升高了-2.50 MPa; 当 $\psi_{\text {soil }}$ 由-0.01 $\mathrm{MPa}$ 降低到 $-0.19 \mathrm{MPa}$ 时, 胡杨 $\psi_{\mathrm{pdl}}$ 由 $-2.50 \mathrm{MPa}$ 升高 到-2.20 MPa, 升高了-0.30 MPa. 由此可知, 在胡杨 和俄罗斯杨未遭受水分胁迫或遭受较弱的水分胁迫 状况下, $\psi_{\mathrm{pds}}, \psi_{\mathrm{m} 1}$ 和 $\psi_{\mathrm{ms}}$ 均可用来反映当时的 $\psi_{\mathrm{soil}}$ 状况, 但 $\psi_{\mathrm{pdl}}$ 不能作为反映 $\psi_{\text {soil }}$ 的合理指标.

\section{3 讨论}

\section{1 胡杨和俄罗斯杨的受旱特性对比}

随着灌溉量从 $0 \mathrm{~m}^{3}$ 增加到 $80 \mathrm{~m}^{3}$ 进而增加到 200 $\mathrm{m}^{3}$, 胡杨午后 $\psi_{\mathrm{s}}$ 的回升现象越来越明显, 说明胡杨 受旱胁迫的强度在逐渐减弱; 俄罗斯杨午后 $\psi_{\mathrm{s}}$ 的
回升现象也越来越明显, $200 \mathrm{~m}^{3}$ 灌溉量后俄罗斯杨 $\psi_{\mathrm{s}}$ 和 $\psi_{1}$ 于 14:00 以后同时回升, 且先于胡杨 $\psi_{\mathrm{s}}$ 回升, 说明实施 $200 \mathrm{~m}^{3}$ 灌溉量后俄罗斯杨受旱胁迫的强度 在逐渐减弱, 且比相同灌溉量下胡杨受旱胁迫的强 度弱.

不论是实施 0,80 还是 $200 \mathrm{~m}^{3}$ 灌溉量, 胡杨 $\psi_{1}$ 均 先于 $\psi_{\mathrm{s}}$ 回升, 这可能是因为在水分亏缺条件下气孔 关闭降低叶片蒸腾, 从而阻止 $\psi_{1}$ 进一步降低, 说明即 使实施 $200 \mathrm{~m}^{3}$ 灌溉量, 仍然不能满足胡杨正常生长, 胡杨仍然处于相对缺水状态. 对于俄罗斯杨, 0 和 $80 \mathrm{~m}^{3}$ 灌溉量后 $\psi_{1}$ 先于 $\psi_{\mathrm{s}}$ 回升, $200 \mathrm{~m}^{3}$ 灌溉量后 $\psi_{1}$ 和 $\psi_{\mathrm{s}}$ 均于 午间 14:00 以后开始回升，说明实施 $200 \mathrm{~m}^{3}$ 灌溉
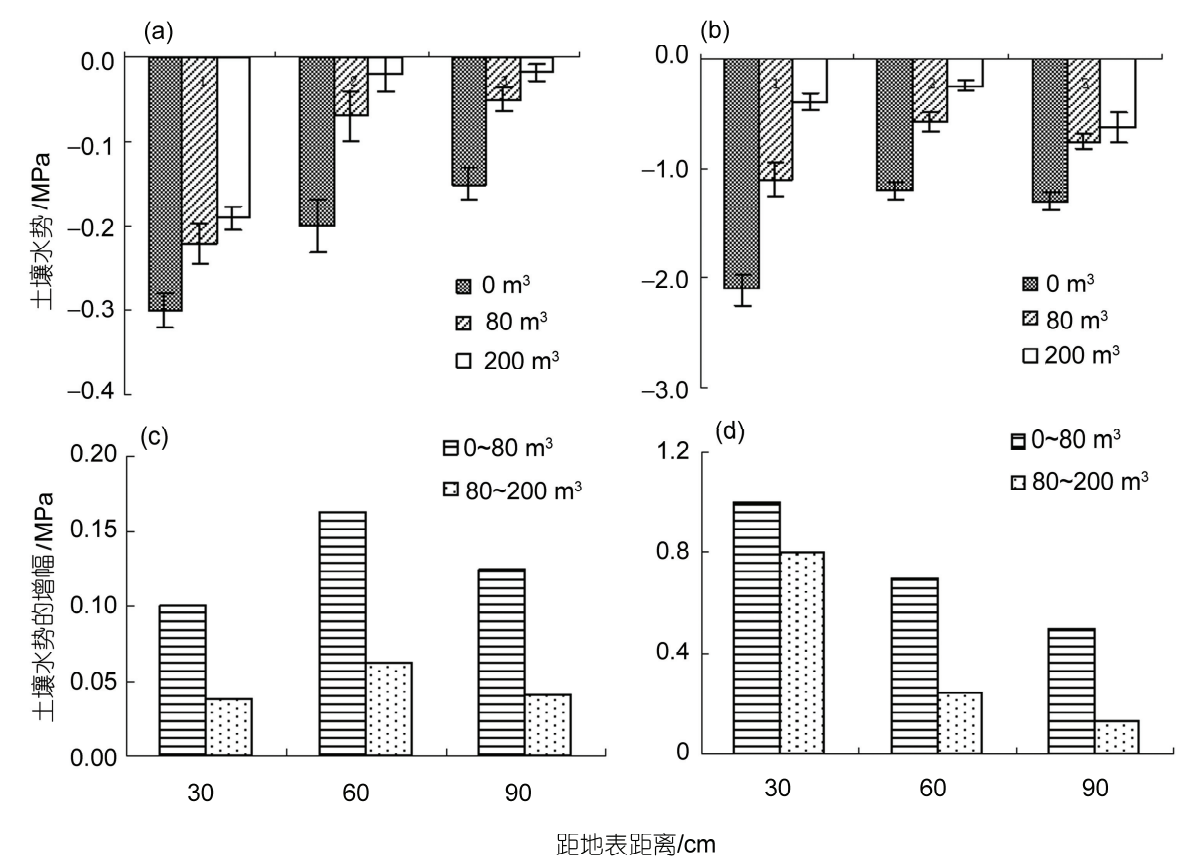

图 4 不同灌溉量下地下 30,60 和 $90 \mathrm{~cm}$ 处土壤水势的日均值和增幅

(a), (c) 胡杨群落; (b), (d) 俄罗斯杨群落
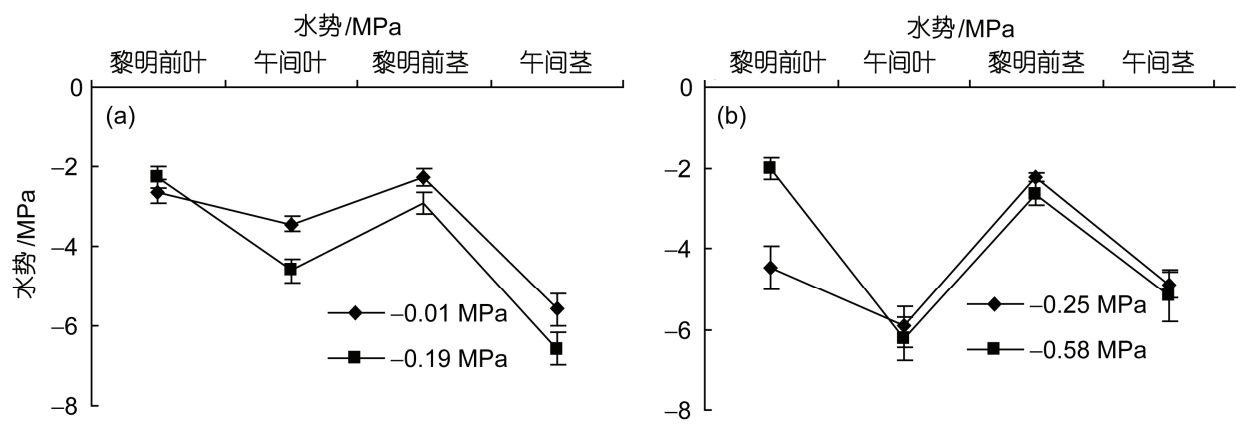

图 5 不同土壤水势下胡杨(a)和俄罗斯杨(b)叶和茎水势 
量后, 俄罗斯杨已不遭受水分胁迫, 可以正常生长.

\section{2 胡杨和俄罗斯杨的抗旱特性对比}

通过对 80 和 $200 \mathrm{~m}^{3}$ 灌溉量下胡杨 $\psi_{1}$ 和 $\psi_{\mathrm{s}}$ 的日变 化特征比较发现, 在 $80 \mathrm{~m}^{3}$ 灌溉量下胡杨 $\psi_{1}$ 和 $\psi_{\mathrm{s}}$ 最低 值出现的时间比俄罗斯杨早, 在 $200 \mathrm{~m}^{3}$ 灌溉量下胡 杨 $\psi_{1}$ 和 $\psi_{\mathrm{s}}$ 最低值出现的时间比俄罗斯杨晚. 由此可 知, 环境越干旱, 俄罗斯杨对干旱反映的敏感程度越 弱, 不能及时采取措施抵抗干旱压力; 环境越湿润, 俄罗斯杨对干旱反映的敏感程度越强, 表现出强烈 的敏感性和脆弱性. 胡杨正好相反, 环境越干旱, 胡 杨对干旱反映的敏感能力越高, 反之亦然. 说明胡杨 对干旱胁迫的忍受能力较强, 抗旱性能较高. $200 \mathrm{~m}^{3}$ 灌 溉量下植物 $\psi_{1}$ 最高值出现的时间比 $80 \mathrm{~m}^{3}$ 灌溉量下晚, 说明 $200 \mathrm{~m}^{3}$ 灌溉量后 $\psi_{\text {soii }}$ 较 $80 \mathrm{~m}^{3}$ 灌溉量后高, 植物 $\psi_{1}$ 达到与 $\psi_{\text {soil }}$ 相平衡时所需时间长. $200 \mathrm{~m}^{3}$ 灌溉量后 胡杨 $\psi_{\mathrm{s}}$ 最高值出现在黎明前, 俄罗斯杨出现在上午 10:00 时刻, 可以推知, 遭受水分胁迫后俄罗斯杨的 恢复能力较胡杨差.

\section{3 不同灌溉量下胡杨和俄罗斯杨群落土壤水势 对比}

胡杨和俄罗斯杨群落 $\psi_{\text {soil }}$ 对不同灌溉量的响应 之所以存在差异, 与胡杨和俄罗斯杨的根系分布不 同有关. 胡杨是干旱荒漠区的物种之一, 在长期适应 干旱胁迫的情况下, 根系具有向水性生长的特性 (http://yz.ag365.com/yangzhi/kejiyuan/2008/2008102246874. $\mathrm{html})$, 当土壤水分向下渗透时, 其根系也不断向下延 伸生长, 同时, 吸收深层土壤水分的能力不断增强. 随着灌溉量的增加, 深根系大量吸水, 在吸水拉力的 作用下，浅根系周围土壤水分不断向深根系周围下 渗并聚拢, 于是, 表现出深层 $\psi_{\text {soil }}$ 较高的情况, 且地 下 $60 \mathrm{~cm}$ 处 $\psi_{\text {soil }}$ 比地下 30 和 $90 \mathrm{~cm}$ 处 $\psi_{\text {soil }}$ 对灌溉量的 变化响应更为强烈; 俄罗斯杨是绿洲区主要绿化树 种, 其根系吸收浅层土壤水分的能力较强, 这种情况 与胡杨正好相反, 所以, 当灌溉量增加时, 不是深根 系大量吸水而是浅根系表现更为强烈, 这种吸水拉 力迫使深层土壤水分向浅层聚拢, 表现出随着灌溉

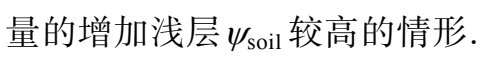

\section{4 胡杨和俄罗斯杨根系吸水特性对比}

对胡杨和俄罗斯杨根系吸水特性对比研究发现,
胡杨群落地下 $60 \mathrm{~cm}$ 处 $\psi_{\text {soil }}$ 的长幅大于地下 30 和 90 $\mathrm{cm}$ 处, 而研究区胡杨根系主要分布在地下 $50 \sim 80 \mathrm{~cm}$ 处, 所以, 增加灌溉量有助于胡杨的生长和发育. 俄 罗斯杨根系主要分布在地下 25 50 cm 处, 对浅层土 壤水分的吸收能力较强, 因此, 随着灌溉量的增多, 浅层 $\psi_{\text {soil }}$ 的长幅大于较深层的现象有利于俄罗斯杨 的生长和发育.

\section{5 土壤水势指标的确定}

通过对不同 $\psi_{\text {soil }}$ 下植物 $\psi$ 变化特征的分析, 发现 当土壤水分较充足时, 植物 $\psi_{\mathrm{pdl}}$ 不能很好地反映当时 的 $\psi_{\text {soil }}$ 状况, 而植物 $\psi_{\mathrm{pds}}, \psi_{\mathrm{ml}}$ 和 $\psi_{\mathrm{ms}}$ 的变化均可反映 当时的 $\psi_{\text {soil }}$ 状况. Donovan 等人 ${ }^{[6]}$ 也研究得出, 当植物 遭受严重的干旱胁迫时, $\psi_{\mathrm{pdl}}$ 能揭示当时的土壤水分 状况; 当土壤水分充足时, $\psi_{\mathrm{pdl}}$ 与根部附近 $\psi_{\text {soil }}$ 不平 衡，不能揭示当时的土壤水分状况. Xavier 等人 ${ }^{[20]}$ 研 究表明, 在判断植物是否遭受干旱胁迫的过程中, $\psi \mathrm{s}$ 是最有鉴别能力的指标. 基于以上研究, 本文进一步 得出 $\psi_{\mathrm{ml}}$ 和 $\psi_{\mathrm{ms}}$ 由于遭受外界环境条件尤其是气候因 子的影响强烈, 故不能作为反映 $\psi_{\text {soil }}$ 状况的合理指标, 只有植物 $\psi_{\mathrm{pds}}$ 可反映当时的 $\psi_{\mathrm{soil}}$ 状况和干旱区植物缺 水或受旱胁迫程度.

\section{4 结论}

胡杨和俄罗斯杨的根系分布和吸水特性有所不 同, 在土壤水分较充足的情况下, 胡杨根系主要分布 在地下 50 80 cm 处, 对较深层土壤水分的吸收能力 较强; 俄罗斯杨根系主要分布在地下 $25 \sim 50 \mathrm{~cm}$ 处, 对浅层土壤水分的吸收能力较强. 因此, 为使其根系 最大程度的发挥各自特点, 最大限度的吸收更多水 分，应采取不同措施. 具体来看，对胡杨防护林来说， 可以采取多量少灌的策略, 在地表灌溉水下渗的同 时, 有效地诱导胡杨根系向地下深部延伸, 使其在干 旱胁迫环境下, 可以汲取土壤耕作层以下的土壤水, 提高胡杨生存的水分自维持能力; 而对俄罗斯杨为 主体的防护林而言, 可以实施少灌多次, 使水分在浅 表层聚集，满足俄罗斯杨对水分的需求.

对不同灌溉条件下胡杨、俄罗斯杨水势变化状况 的试验研究表明, $200 \mathrm{~m}^{3}$ 灌溉量可以满足俄罗斯杨正 常生长所需, 实施少灌多次, 可节约水量, 提高水分 利用效率; $200 \mathrm{~m}^{3}$ 灌溉量不能满足胡杨正常生长, 为 
使胡杨不遭受水分胁迫, 实施的灌溉量必须大于 $200 \mathrm{~m}^{3}$, 适当增加每次灌溉水量, 可提高胡杨的水分 利用效率.
在土壤水分较充足的情况下, 植物 $\psi_{\mathrm{pds}}$ 能有效反 映当时的 $\psi_{\text {soil }}$ 状况和干旱区植物缺水或受旱胁迫的 程度。

\section{参考文献}

1 司建华, 冯起, 张小由. 极端干旱区胡杨水势及影响因子研究. 中国沙漠, 2005, 25: 505一 510

2 Vogt U K, LÖsch R. Stem water potential and leaf conductance: A comparison of Sorbus aucuparia and Sambucus nigra. Phys Chem Earth(B), 1999, 24: 121-123

3 Morte A, Lovisolo C, Schubert A. Effect of drought stress on growth and water relations of the mycorrhizal association Helianthemum almeriense-Terfezia claveryi. Mycorrhiza, 2000, 10: 115-119

4 Zhu L H, Peppel A V D, Li X Y, et al. Changes of leaf water potential and endogenous cytokinins in young apple trees treated with or without paclobutrazol under drought conditions. Sci Horticul, 2004, 99: 133-141

5 Mrema A F, Granhall U. Sennerby-Forsse plant growth, leaf water potential, nitrogenase activity and nodule anatomy in Leucaena leucocephala as affected by water stress and nitrogen availability. Trees-struc Funct, 1997, 12: 42-48

6 Donovan L A, GrisêA D J, West J B, et al. Predawn disequilibrium between plant and soil water potentials in two cold-desert Shrubs. Oecologia, 1999, 120: 209-217

7 Cutchan M, Sehackel H K A. Stem-water potential as a sensitive indicator of water stress in prune trees (Prunus domestica L.). J Am Soc Hort Sci, 1992, 117: 607-611

8 Atklnson C J, Policarpo M, Webster A D, et a1. Drought tolerance of clonal Malus determined from measurements of stomatal conductance and leaf water potential. Tree Physio1, 2000, 20: 557-563

9 白瑞琴, 孙丽华, 吕占江, 等. 不同砧木苹果树水势日变化的研究. 内蒙古农业大学学报(自然科学版), 2000, 21: 63一 68

10 曾凡江, 张希明, 李向义. 塔克拉玛干沙漠南缘柽柳和胡杨水势季节变化研究. 应用生态学报, 2005, 30: 108一114

11 Sílvia F, Dora B, Susana S, et al. Morphogenesis induction and organosenic nodule differentiation in Populus euphratica Oliv leaf explants. Plant Cell Tiss Org, 2009, 96: 35-43

12 蒙敏, 蒋衡, 何江成. 俄罗斯杨组培快繁技术研究. 新疆农业科学, 2003, 40: 101-102

13 Wang Q, Ruan X, Chen Y N, et al. Eco-physiological response of Populus euphratica Oliv to water release of the lower reaches of Tarim River, China. Environ Geol, 2007, 53: 349-357

14 Saito Y, Shiraishi S, Tanimoto F, et al. Genetic diversity of Populus euphratica populations in northwestern China determined by RAPD DNA analysis. New For, 2002, 23: 97-103

15 Watanabe S, Kojima K, Ide Y, et al. Effects of saline and osmotic stress on proline and sugar accumulation in Populus euphratica in vitro. Plant Cell Tiss Org, 2000, 63: 199-206

16 Gu R S, Liu Q L, Pei D, et al. Understanding saline and osmotic tolerance of Populus euphratica suspended cells. Plant Cell Tiss Org, 2004, 78: 261-265

17 宋耀选，周茂先，张小由，等. 额济纳绿洲主要植物的水势与环境因子的关系. 中国沙漠, 2005, 25: 496-499

18 Gries D, Zeng F, Foetzki A, et al. Growth and water relations of Tamarix ramosissima and Populus euphratica on Taklamakan desert dunes in relation to depth to a permanent water table. Plant Cell Environ, 2003, 26: 725-736

19 李丕军, 李宏, 牙合提·古丽. 俄罗斯杨夏季扦插造林技术研究初报. 新疆农业科学, 2005, 42: 32-34

20 Xavier C, Cornelis L, Denis D, et al. Stem water potential is a sensitive indicator of grapevine water status. Ann Bot, 2001, 87: 477-483 